\title{
Hydrogel effects in biochemical composition of soybean grains cultivated under water deficit in Brazilian Cerrado
}

\author{
Vitor L. Nascimento*, Wagner A. Rauber, Guilherme S. Silva, Susana C. Siebeneichler and Rodrigo R. Fidelis*
}

Federal University of Tocantins, Gurupi, TO, Brazil

*Authors for correspondence: vitorInasc@gmail.com, fidelisrr@uft.edu.br

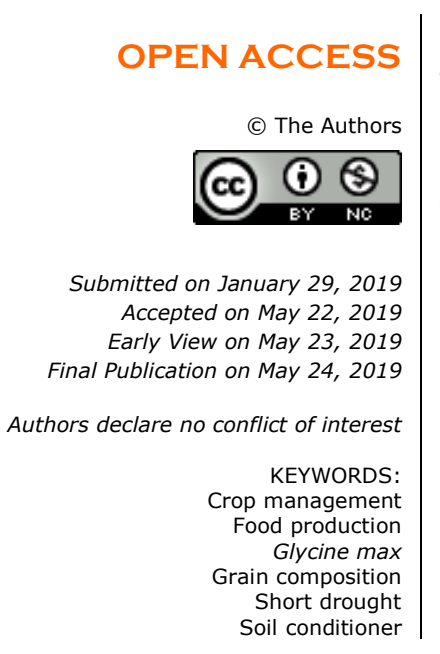

\section{ABSTRACT}

The aim of this work was to verify the influence of hydrogel application during plant development on the biochemical composition of soybean grains. The experiment was carried out in a randomized complete block design with four replicates, in a $5 \times 2$ factorial scheme, with five concentrations $\left(0,5,10,15\right.$ and $\left.20 \mathrm{~kg} \mathrm{ha}^{-1}\right)$ and two hydrogels sources (Hydroplan and Polim-Agri). The soybean cultivar used was MonSoy 8644 .The biochemical contents evaluated were: oil, soluble carbohydrates, amino acids, starch, and proteins. The use of hydrogel was an alternative for grain production, since there no major changes in the contents of the biochemical compounds analyzed here.

\section{Highlighted Conclusions}

1) The use of hydrogel for the maintenance of soybean yield when cultivated in water deficit do not impaired the grain biochemical quality.

2) There is an interaction between carbohydrates and proteins levels, but not between oil and proteins in the treatment with hydrogel's doses.

\section{INTRODUCTION}

Soybean (Glycine $\max (\mathrm{L})$ Merrill) is a legume that stands out as one of the main crops produced in Brazil and world being characterized as a source of energy (carbohydrates and lipids), proteins and phytochemicals important in different metabolic activities. In addition, it is a good source of minerals such as iron, potassium, magnesium, zinc, copper, phosphorus and manganese, and is still considered a functional food because it has several health benefits, helping to reduce the risk of developing chronic and degenerative diseases (Penha et al. 2007, Silva et al. 2012). The biochemical composition of the grain may vary depending on genetic and environmental factors (Mazur et al. 1999) and among these, water availability is considered the factor with the greatest impact on grain production and quality (Veiga et al. 2010). Understand the factors that affects the biochemical composition of soybeans is of fundamental interest as much as it is thought in the grain as in its derivatives for the industry (Pires et al. 2006, Berno et al. 2007, Minuzzi et al. 2009, Oliveira et al. 2010).

The Tocantins State presents great productive potential for soybean because it is in full agricultural expansion thanks to the great availability of areas for cultivation and good water availability, where the average annual rainfall varies from 1,500 to 2,100 $\mathrm{mm}$ (Silva-Junior 2016). On the other hand, in a great part of these areas there is a scenario with irregular distribution of rains when the cultivation is done, being common the occurrence of droughts, denominated regionally like "short drought" (Ayoade 2010). This short drought phenomenon can cause serious decreases in soybean yield because they are associated with the low water retention capacity of soils, together with the high evapotranspiration demand of the atmosphere (Ferrari et al. 2015).

Water availability has been considered the climatic factor with major effect on agricultural productivity since crops under stress have a reduction in the germination and vigor of newly emerged seeds and seedlings (Fioreze et al. 2011). The water deficit causes physiological changes, such as reduction of water potential, stomatal closure, reduction of photosynthetic rate, morphological rate, reduction of shoot, weight and area, acceleration of senescence, foliar abscission, among others (Ferrari et al. 2015). This stress in the vegetative stage reduces the growth of the plant, thus compromising the yield of grains in the reproductive phase (Pereira et al. 2012). The oil and protein contents of soybeans are genetically governed, but they are strongly influenced by the environment during the period of grain filling (Rangel et al. 2004, Minuzzi et al. 2009). In addition, the protein content in the 
grains is four times more dependent on environmental conditions than genetic traits (Benzian and Lane 1986). In this way, cultural practices that minimize the effects of water deficit are fundamental to reduce losses in soybean crops, productivity and grain quality. Hence, hydrogels, as soil conditioners, can act as a water reserve for the plant, and making it available in times of water deficit, improving plant development and yield (Venturoli and Venturoli 2011, Lopes 2016, Lopes et al. 2017).

Hydrogels are defined as superabsorbent polymers consisting of one, or more, three-dimensionally structured networks formed by macromolecular chains interconnected by covalent bonds or physical interactions which can retain a significant amount of water within its own structure and dilate without dissolving the same (Liang et al. 2007, Aouada et al. 2008, Oviedo et al. 2008). These polymers have been used to increase water retention capacity, improving soil properties and reducing nutrient leaching, thus allowing an effective use of soil and water resources, contributing to crop development and yield, germination time, reduction of plant mortality and root system development (Azevedo et al. 2002). In Brazil, some hydrogels have been used in the production of fruits, vegetables and seedlings of the most diverse species, such as the formation of lawns in gardens, football fields and golf courses (Oliveira et al. 2004). The use of hydrogels in soybean and cowpea crops has shown to be an alternative potential for reducing productivity losses resulting from the action of the water deficit, by short drought (Lopes 2016, Lopes et al. 2017). Considering that, since this polymer acts beneficially in the control of water stress, reducing its impact on productivity, it is necessary to characterize the possible changes in the biochemical quality of the grains. Therefore, the objective of this study was to evaluate the effect of hydrogel, different sources and concentrations, on the biochemical composition of soybean grown under water stress.

\section{MATERIAL AND METHODS}

The experiment was carried out in the 2015/2016 crop season, in the Experimental Station of the Universidade

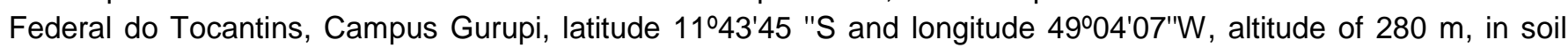
classified as dystrophic Red-Yellow Oxisol (Embrapa 2013). The climate of the region, according to classification of Köppen, is of the mesothermic type with rains of summer and dry winter (Alvares et al. 2014). During the $2015 / 2016$ crop season, there was drought of approximately 30 days, a short drought, when the plants had about 45 days of sowing and were in the reproductive stage, between the flowering and the grains filling (Lopes 2016). The biochemical composition of the grains was evaluated in the Plant Ecophysiology Laboratory of Universidade Federal do Tocantins, Campus Gurupi. For this study the soybean cultivar MonSoy 8644 was used with two sources of hydrogels and five concentrations of the products, in a total of totaling ten treatments. The experimental design was a randomized block design (DBC), with four replicates, in a $5 \times 2$ factorial scheme, with five product concentrations $\left(0,5,10,15\right.$ and $\left.20 \mathrm{~kg} \mathrm{ha}^{-1}\right)$ and two hydrogel sources (Hydroplan and Polim-Agri), in the seedling line in soil during the planting, according to Lopes (2016) and Fidelis et al. (2018).

In order to verify the hydrogels effect on the biochemical composition of the soybean grains were evaluated: (1) oil content (\%); (2) soluble carbohydrate content ( $\left.\mathrm{mg} \mathrm{g}^{-1}\right)$; (3) amino acid content $\left(\mathrm{mg} \mathrm{g}^{-1}\right)$; (4) starch content $\left(\mathrm{mg} \mathrm{g}^{-1}\right)$; and $(5)$ protein content $\left(\mathrm{mg} \mathrm{g}^{-1}\right)$. Soybean grains were previously ground in Willye Knife Mill, STAR FT 50.

In the oil content determination, $750 \mathrm{mg}$ of each sample were used, and $3 \mathrm{~mL}$ of analytical hexane were added, followed by vortex homogenization for $30 \mathrm{~s}$ and resting for $20 \mathrm{~min}$. Subsequently the samples were centrifuged at $3,500 \mathrm{rpm}$ for $30 \mathrm{~min}$ at room temperature. The supernatant was discarded, and the procedure repeated to ensure complete removal of the oil and the precipitate was oven dried at $50{ }^{\circ} \mathrm{C}$ to constant weight. The results were expressed as percentage (\%) of extracted oil, determined by weighing difference of the defatted sample (Castro 2016). After quantification of the oil content, the precipitate became the basis for further quantifications.

For the other biochemical components' extraction, $100 \mathrm{mg}$ of the previously used samples were used for oil content, in which $3 \mathrm{~mL}$ of ethanol $80 \%$ were added and them were then incubated in a water bath at $80{ }^{\circ} \mathrm{C}$ for $30 \mathrm{~min}$. After resting for $5 \mathrm{~min}$ to lower the temperature, they were centrifuged at 3,500 rpm for $10 \mathrm{~min}$. The supernatant was collected, and this procedure was repeated twice. The supernatants were pooled in the same tube and the precipitates were oven dried.

From the supernatant of the ethanolic extraction were carried out the quantifications of soluble carbohydrates and amino acids contents. The quantification of soluble carbohydrates was carried out by the reaction with phenolsulfuric acid (Dubois et al. 1956). In $100 \mu \mathrm{l}$ of the supernatant was added $400 \mu \mathrm{L}$ of distilled water and vortexed. Then, $500 \mu \mathrm{L}$ of $5 \%$ phenol was added and the samples were vortexed. Subsequently, $2.5 \mathrm{~mL}$ of concentrated sulfuric acid was added, followed by vortex. After resting for 20 minutes, the absorbance sample readings were performed in a spectrophotometer (SP-220 - BIOSPECTRO®) at $490 \mathrm{~nm}$. A standard curve $(y=0.0053 x+0.1456$ with $R^{2}=0.9718$ ) was performed using glucose under the same analysis procedure to calculate the soluble carbohydrates concentration. The unity used was $\mathrm{mg}$ of glucose per $\mathrm{g}$ of grains. 
For the quantification of amino acids, the methodology was based on the reaction of ninhydrin (Friedman 2004). In $200 \mu \mathrm{l}$ of the supernatant was added $300 \mu \mathrm{L}$ of distilled water and vortexed. Subsequently, $250 \mu \mathrm{L}$ of sodium-citrate buffer and $250 \mu \mathrm{L}$ of ethanolic ninhydrin (70\%) were added, vortexed again and the hermetically sealed tubes were incubated in a water bath for $15 \mathrm{~min}$ at $100^{\circ} \mathrm{C}$. To interrupt the reaction, the tubes were taken to the ice bath, and then the absorbance reading in a spectrophotometer at $570 \mathrm{~nm}$. A standard curve $(y=0.0053 x-$ 0.187 with $R^{2}=0.9368$ ) was performed using tryptophan under the same analysis procedure to calculate the amino acids concentration. The unity used was $\mathrm{mg}$ of tryptophan per $\mathrm{g}$ of grains.

From the precipitate of the ethanolic extraction were carried out the quantifications of starch and proteins contents. The starch analysis was performed with a step of breaking the molecule with perchloric acid, followed by quantification using the phenol-sulfuric acid (Dubois et al. 1956, Macrae et al. 1974). In $50 \mathrm{mg}$ of the ethanol extraction precipitate were added $2 \mathrm{~mL}$ of perchloric acid and placed for centrifugation at 3,500 rpm for 10 minutes. The supernatant was collected and stored. Extraction was repeated, and the supernatants were pooled. For quantification, $50 \mu \mathrm{L}$ of this supernatant was added to the test tube, $450 \mu \mathrm{L}$ of distilled water was added and vortexed. $500 \mu \mathrm{L}$ of $5 \%$ phenol was added and vortexed again. $2.5 \mathrm{ml}$ of concentrated sulfuric acid was added, followed by vortex. After resting for 20 minutes, the sample were read at $490 \mathrm{~nm}$ the spectrophotometer absorbance. A standard curve $\left(y=0.0053 x+0.1456\right.$ with $\left.R^{2}=0.9718\right)$ was performed using glucose under the same analysis procedure to calculate the starch concentration. The unity used was $\mathrm{mg}$ of glucose per $\mathrm{g}$ of grains.

The quantification of proteins was performed according to the Bradford (1976). In $50 \mathrm{mg}$ of the ethanol extraction precipitate were added $2 \mathrm{~mL}$ of $0.2 \mathrm{M}$ potassium hydroxide followed by vortex homogenization. Samples were incubated in a $95{ }^{\circ} \mathrm{C}$ water bath for 1 hour and the reaction was stopped in an ice bath for 5 minutes. For the quantification, $20 \mu \mathrm{L}$ of the sample and $280 \mu \mathrm{L}$ of distilled water were used, the samples were vortexed. Then $1 \mathrm{~mL}$ of Bradford's reagent (Bio-Rad Laboratories, Inc.) was added, followed by vortex homogenization and standing for 15 minutes. Absorbance readings were performed in a spectrophotometer at $595 \mathrm{~nm}$. A standard curve $(\mathrm{y}=$ $0.0076 x+0.1626$ with $R^{2}=0.9558$ ) was performed using bovine serum albumin (BSA) under the same analysis procedure to calculate the protein concentration. The unity used was mg of BSA per $\mathrm{g}$ of grains.

The experimental data were submitted to analysis of variance and, when significant by the $F$ test, the regression test was applied using statistical software $R$ ( $R$ Core Team 2017).

\section{RESULTS AND DISCUSSION}

The results of the analysis of variance are presented in Table 1. For the characteristic protein content, there was no interaction, showing that the factors are independent and being isolated. In the other characteristics, a significant effect was observed for interaction, thus evidencing that they are dependent factors, and therefore, the unfolding the factors. Table 1 shows the coefficients of variation for each evaluated characteristic and for the oil, protein and amino acid contents the values are low and for the characteristic's soluble carbohydrate and starch contents the coefficients of variation are conform to the average value established as acceptable (Pimentel-Gomes 2000).

Table 1. Summary of variance analysis of the characteristics: oil, soluble carbohydrates, amino acids, starch, and protein contents in soybean grains grown in the southern of Tocantins State.

\begin{tabular}{|c|c|c|c|c|c|c|}
\hline \multirow{2}{*}{ Factors } & \multirow{2}{*}{$\begin{array}{l}\text { Degrees of } \\
\text { freedom }\end{array}$} & \multicolumn{5}{|c|}{ MEAN SQUARES } \\
\hline & & Oil & Carbohydrates & Amino acids & Starch & Protein \\
\hline Source (S) & 1 & $6.0996^{* *}$ & $5135.0^{* *}$ & $402.65^{*}$ & $2859.48^{*}$ & $109.96^{\text {ns }}$ \\
\hline Doses (D) & 4 & $0.6862^{\text {ns }}$ & $1476.8^{* *}$ & $317.84^{* *}$ & $1388.69^{\text {ns }}$ & $3085.47^{*}$ \\
\hline$S \times D$ & 4 & $5.3192^{* *}$ & $1066.7^{* *}$ & $582.74^{* *}$ & $2784.91^{* *}$ & $507.42^{\text {ns }}$ \\
\hline Residue & 30 & 0.3608 & 188.3 & 69.63 & 636.12 & 949.4 \\
\hline CV (\%) & & 2.97 & 15.73 & 8.66 & 21.71 & 9.32 \\
\hline Average & & 20.25 & 87.24 & 96.36 & 116.19 & 330.75 \\
\hline
\end{tabular}

For the characteristic oil content (Figure 1A), analyzing the unfolding of the hydrogel sources within doses, for the Polim-Agri hydrogel source was verified a higher estimated content of $21.60 \%$ in the dose of $4.62 \mathrm{~kg} \mathrm{ha}^{-1}$. As for the Hydroplan hydrogel source, the maximum estimated point is $21.10 \%$ at the dose of $15.84 \mathrm{~kg} \mathrm{ha}^{-1}$. However, due to the behavior of the data, it can be interpreted that in practice there was no change in the oil content in the analyzed grains as a function of doses and sources, and the observed variation is within the expected and demonstrated in the literature. In the extraction used, mean values of $20.25 \%$ were obtained, which is the standard described in the most diverse studies analyzing the lipid composition of soybean grains, such as storage time 
(Alencar et al. 2009), treatment with plant growth promoters (Albrecht et al. 2012), comparison of cultivars and cultivation site (Minuzzi et al. 2009), treatments with supplementation in potassium fertilization (Veiga et al. 2010), among others, demonstrating that the hydrogel treatment is not harmful to the oil content in the soybean grains and that the extraction and quantification methodology used is reliable for the analyzed characteristic.
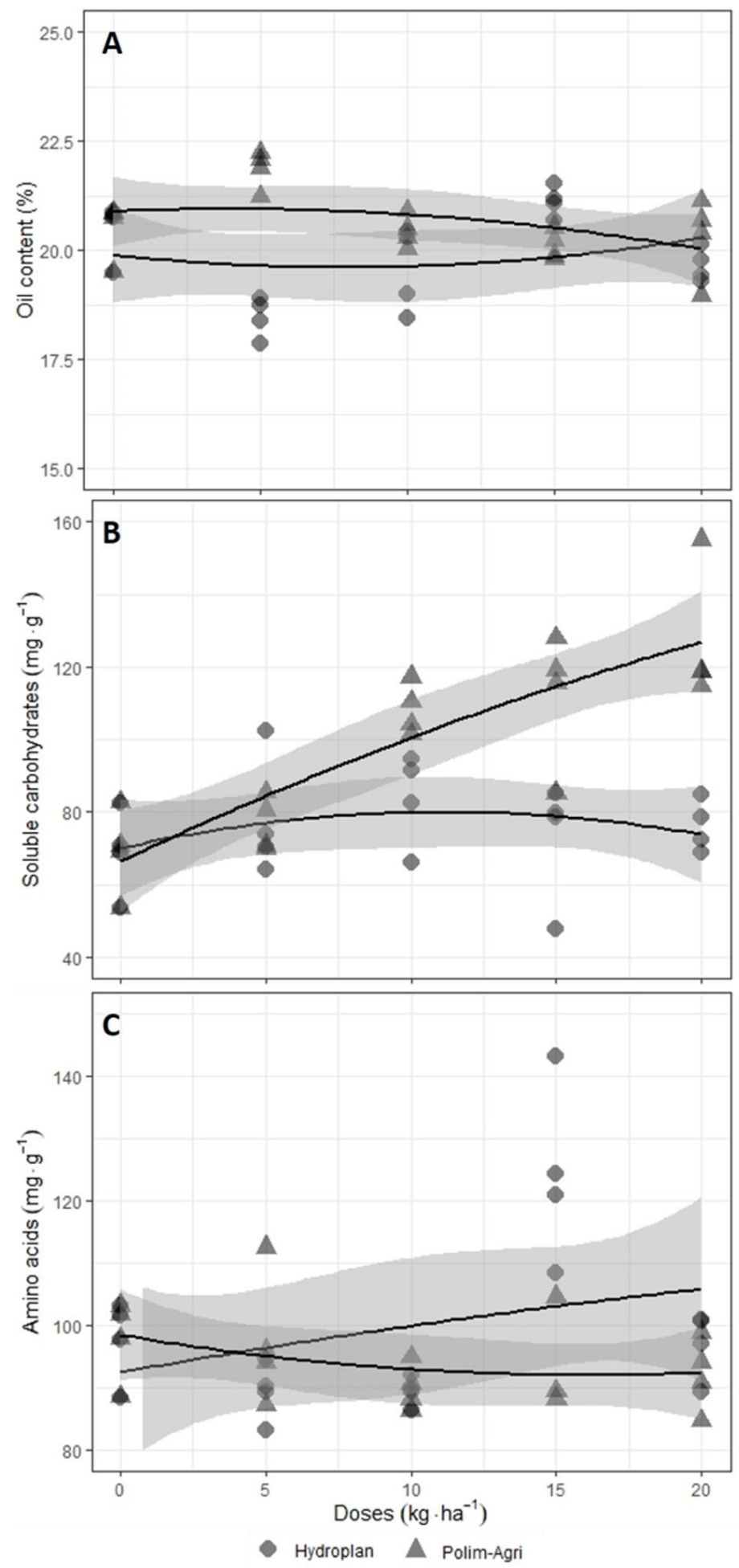

Figure 1. Variation of oil (A), soluble carbohydrates (B) and amino acids (C) contents as a function of interaction between two hydrogel sources (Hydroplan and Polim-Agri) and five doses (0, 5, 10, 15 and $20 \mathrm{~kg} \mathrm{ha}^{-1}$ ).

In relation to the soluble carbohydrates content (Figure 1B), analyzing the unfolding of the hydrogel sources within doses, there were higher responses to the Polim-Agri source, which presented increasing response with increasing doses. However, the plants that received treatment with the Hydroplan source did not present significant differences between doses. The carbohydrates in soybean grains are generally quantified indirectly, and therefore, 
the variation described in the literature is wide ranging from $17 \%$ in studies comparing the carbohydrate content in grains and their derivatives (Silva et al. 2006) to $35 \%$ in studies comparing conventional and transgenic soybeans (Alezandro et al. 2008). In this study, about $10 \%$ of soluble carbohydrates were found, which is close to $8 \%$ described by Oliveira et al. (2010) which used most expensive methodologies to quantify the soluble carbohydrate content of different soybean cultivars destined for human consumption. This proximity to the values found by other studies shows the potential of the methodology used and that the differences found in hydrogel treatments are in fact very pertinent and interesting.

As for the amino acid content (Figure 1C), the Hydroplan source obtained higher levels at $15.69 \mathrm{~kg} \mathrm{ha}^{-1}$, with an estimated maximum point of $117.56 \mathrm{mg} \mathrm{g}^{-1}$. With the Polim-Agri source there was a decrease of the contents due to the increase of the doses, being this same hydrogel source that presented increase in the soluble carbohydrates content. The amino acid variable is a little more complex to compare since it is not common to use the quantification of the total amino acid content in soybean grains by the ninhydrin method, using different techniques, which are more expensive (Pires et al. 2006, Silva et al. 2006). It should be noted that soybeans may be sources of several amino acids for feeding and further studies are needed to characterize these biochemicals.

In relation to the starch content (Figure 2A), analyzing the unfolding of the hydrogel sources within the doses, it is observed that, for Polim-Agri source there is quadratic and increasing response in the starch content due to the increase of the doses. As for the source Hydroplan, with increasing doses, there is a decrease in the starch content. For both the total soluble carbohydrate (Figure 1A) and the starch (Figure 2A) contents, for the Polim-Agri source, there was a significant increase in the doses, demonstrating that there was a greater translocation of photoassimilates to the seeds, to the efficiency of the products in retaining water even in the condition of water stress and provides it to soybean plants. The average starch content, slightly more than $1 \%$ of the mass of the grain, agrees with that described for soybean grains of different cultivars for human consumption (Oliveira et al. 2010).
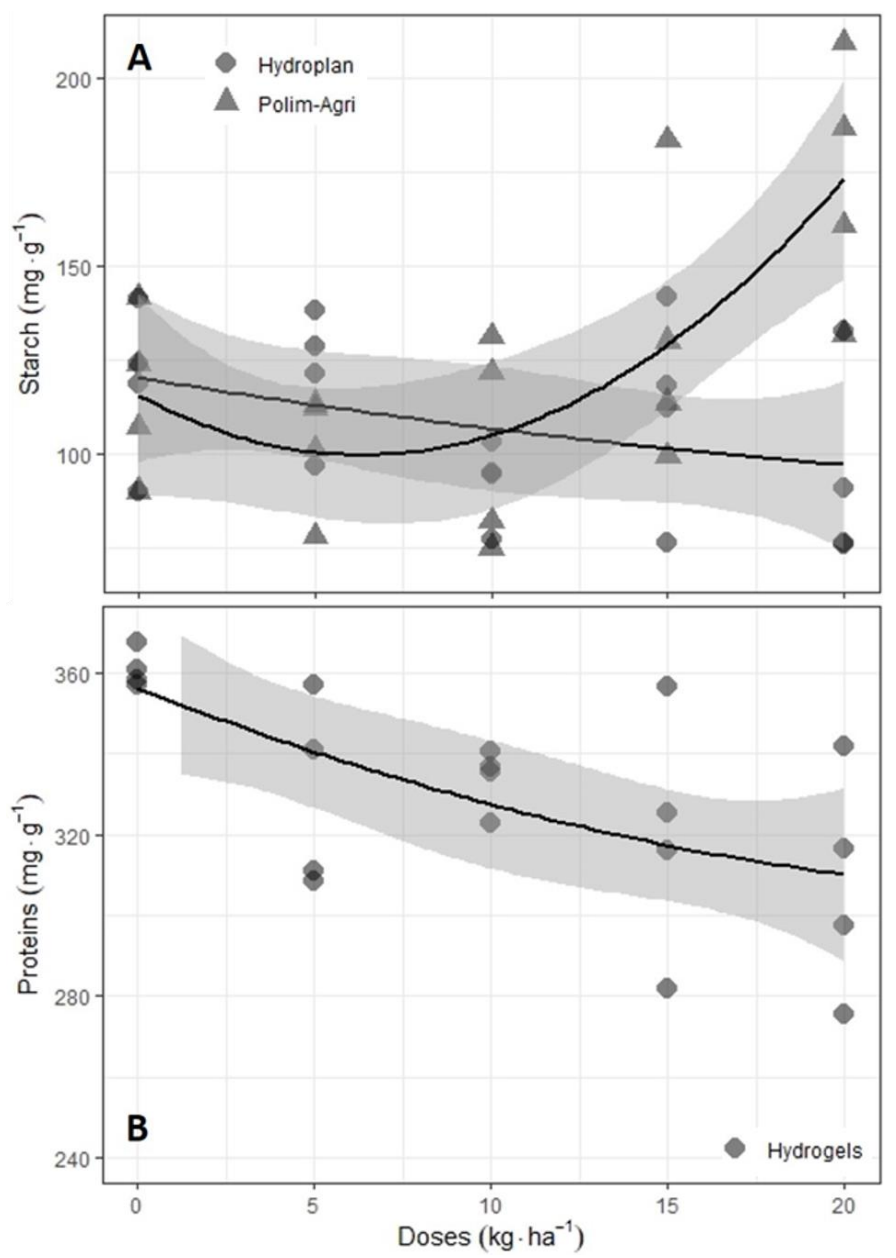

Figure 2. Variation of the starch content as a function of the interaction between two sources of hydrogel (Hydroplan and Polim-Agri) and five doses $\left(0,5,10,15\right.$, and $\left.20 \mathrm{~kg} \mathrm{ha}^{-1}\right)(\mathrm{A})$. Variation of protein content as a function of hydrogel doses $\left(0,5,10,15\right.$ and $\left.20 \mathrm{~kg} \mathrm{ha}^{-1}\right)(B)$. 
In relation to the protein content (Figure 2B), a decrease was observed in relation to the increase of the doses of the hydrogel. Excessive rainfall during the development of soybean plants displays a negative correlation, decreasing the protein content (Kumar et al. 2006). In this sense, the increase of the hydrogel doses promoted a greater retention of water for the plant, resulting in the reduction of the protein content. Despite this decrease, the average found in this study (33.08\%) is near to the average found by other studies as in treatment with different desiccants (Lacerda et al. 2003), different cultivars and crop sites (Minuzzi et al. 2009), in selected cultivars with high iron content (Yamada et al. 2003), the comparison between conventional and transgenic soybean plants (Ciabotti et al. 2006, Alezandro et al. 2008), evidenced the hydrogel's potential to maintain the yield of the soybean crop cultivated under deficit without losing biochemical quality, which is of extreme importance, since it is possible to put in the market more quantity of food.

The increase in protein content may reduce the soluble carbohydrates present in the cells, thus showing the negative correlation between these two characteristics (Hartwig et al. 1997, Wilcox and Shibles 2001). In the present work, this negative correlation was evidenced to the opposing, in that with the reduction of proteins (2B) and amino acids (1C) contents, there was an increase in the soluble carbohydrate (Figure 1B) and starch (Figure 2A) contents, for source Polim-Agri. This relationship is very interesting because the most common is a change in oil and protein content, and a negative correlation, such as when treatment with growth promoters occurs (Albrecht et al. 2012).

Finally, the methodology adopted here with a single step for ethanolic extraction associated with the quantification of major biochemical components of grains by classical spectrophotometric analysis is not commonly found in the literature.

The use of hydrogel is already validated as an important and useful treatment for the maintenance of soybean yield when cultivated in water deficit, caused by short drought, but here we demonstrate that the biochemical quality is not impaired. There is an interesting interaction between carbohydrates and proteins and not between oil and proteins in the treatment with doses of hydrogel.

\section{References}

Albrecht LP et al. 2012. Biorregulador na composição química e na produtividade de grãos de soja. Revista Ciência Agronômica 43:774-782.

Alencar ER et al. 2009. Qualidade dos grãos de soja armazenados em diferentes condições. Revista Brasileira de Engenharia Agrícola e Ambiental 13:606-613.

Alezandro MR et al. 2008. Soja transgênica BRS 243 RR: determinação de macronutrientes e das isoflavonas daidzeína e genisteína por Cromatografia Líquida de Alta Eficiência (CLAE). Ciência e Tecnologia de Alimentos 28:520-526.

Alvares CA et al. 2014. Koppen's climate classification map for Brazil. Meteorologische Zeitschrift 22:711-728.

Aouada FA et al. 2008. Caracterização de hidrogéis condutores constituídos por PAAm e PEDOT/PSS por meio de planejamento fatorial. Polímeros: Ciência e Tecnologia 18:126-131.

Ayoade JO. 2010. Introdução a Climatologia para os trópicos. 14ํed, Bertrand Brasil: Rio de Janeiro.

Azevedo TLF et al. 2002. Uso de hidrogel na agricultura. Revista do Programa de Ciências Agro-Ambientais 1:23-31.

Benzian B and Lane PW. 1986. Protein concentration of grains in relation to some weather and soil factors during 17 years of English winterwheat experiments. Journal of Science of Food and Agriculture 37:435-444.

Berno LI et al. 2007. Avaliação da composição centesimal Digestibilidade e Atividade Inibitória de Tripsina em produtos derivados de soja (Glycine max). Alimentos e Nutrição 18:277-282.

Bradford MM. 1976. A rapid and sensitive method for the qualification of microgram quantities of protein utilizing the principle of protein dye binding. Analytical Biochemistry 7:248-254.

Castro RG. 2016. Desempenho agronômico, qualidade fisiológica e atividade enzimática de sementes de soja sob diferentes doses de glifosato. Dissertation, Universidade Federal de Lavras, Minas Gerais, Brasil.

Ciabotti $S$ et al. 2006. Avaliações químicas e bioquímicas dos grãos, extratos e tofus de soja comum e de soja livre de lipoxigenase. Ciência e Agrotecnologia 30:920-929.

Dubois $\mathrm{M}$ et al. 1956. Colorimetric method for determination of sugars and related substances. Analytical Chemistry 28:350-356.

Embrapa - Empresa Brasileira de Pesquisa Agropecuária. 2013. Sistema Brasileiro de Classificação de Solos. 3 ed. Centro Nacional de Pesquisa de Solos Embrapa: Brasília.

Ferrari E et al. 2015. Déficit hídrico no metabolismo da soja em semeaduras antecipadas no Mato Grosso. Nativa 3:67-77.

Fidelis RR et al. 2018. Influence of hydrogel use on soybean cultivation hydrical stress. Bioscience Journal 34:1219-1224.

Fioreze SL et al. 2011. Comportamento de genótipos de soja submetidos a déficit hídrico intenso em casa de vegetação. Revista Ceres 58:342-349.

Friedman M et al. 2004. Applications of the ninhydrin reaction for analysis of amino acids, peptides, and proteins to agricultural and biomedical sciences. Journal of Agricultural and Food Chemistry 52:385-406.

Hartwig EE et al. 1997. Seed protein and its relationship to soluble sugars in soybean. Crop Science 37:770-773.

Kumar A et al. 2006. Influence of growing environment on the biochemical composition and physical characteristics of soybean seed. Journal of Food Composition and Analysis 19:188-185.

Lacerda ALS et al. 2003. Armazenamento de sementes de soja dessecadas e avaliação da qualidade fisiológica, bioquímica e sanitária.

Revista Brasileira de Sementes 25:97-105. 
Liang R et al. 2007. Controlled release NPK compound fertilizer with the function of water retention. Reactive and Functional Polymers 67:769779.

Lopes MBS. 2016. Hidrogéis como alternativa no aumento da capacidade de retenção de água no solo para cultura da soja e do feijão caupi. Thesis, Universidade Federal do Tocantins, Brasil.

Lopes MBS et al. 2017. Cowpea bean production under water stress using hydrogels. Pesquisa Agropecuaria Tropical 47:87-92.

Macrae JC et al. 1974. Starch estimation in leaf tissue - a comparison of results using six methods. Journal of the Science of Food and Agriculture 25:1465-1469.

Mazur B et al. 1999. Gene Discovery and Product Development for Grain Quality Traits. Science 285:372-375.

Minuzzi A et al. 2009. Rendimento, teores de óleo e proteínas de quatro cultivares de soja, produzidas em dois locais no estado do Mato Grosso do Sul. Ciência e Agrotecnologia 33:1047-1054.

Oviedo IR et al. 2008. Design of a Physical and Nontoxic Crosslinked Poly (Vinyl Alcohol) Hydrogel. International Journal of Polymeric Materials and Polymeric Biomaterials 57:1095-1103.

Oliveira RA et al. 2004. Influência de um polímero hidroabsorvente sobre a retenção de água no solo. Revista Brasileira de Engenharia Agrícola e Ambiental 8:160-163.

Oliveira MA et al. 2010. Quantificação dos teores de açúcares, oligossacarídeos e amido em genótipos/ cultivares de soja (Glycine max (L) Merril) especiais utilizados para alimentação humana. Brazilian Journal of Food Technology 13:23-29.

Penha LAO et al. 2007. A soja como alimento: valor nutricional, benefícios para a saúde e cultivo orgânico. Boletim do Centro de Pesquisa de Processamento de Alimentos 25:91-102.

Pereira JWL et al. 2012. Mudanças bioquímicas em genótipos de amendoim submetidos a déficit hídrico moderado. Revista Ciência Agronômica 43:766-773.

Pimentel-Gomes F. 2000. Curso de estatística experimental. 14ํed. Degaspari: Piracicaba.

Pires CV et al. 2006. Qualidade nutricional e escore químico de aminoácidos de diferentes fontes protéicas. Ciência e Tecnologia de Alimentos 26:179-187.

Rangel MAS et al. 2004. Efeito do genótipo e do ambiente sobre os teores de óleo e proteína nos grãos de soja, em quatro ambientes da Região Sul de Mato Grosso do Sul, safra 2002/2003. Boletim de pesquisa e desenvolvimento. Embrapa Agropecuária Oeste: Dourados.

R Core Team. 2017. R: A language and environment for statistical computing. R Foundation for Statistical Computing, Vienna, Austria. 2017. https://www.R-project.org/.

Silva-Junior JLC. 2016. Avaliação parcial das condições pluviométricas no Estado do Tocantins, durante o período chuvoso 2015/2016. Relato técnico-científico. Fundação UNITINS.

Silva MS et al. 2006. Composição Química e Valor Protéico do Resíduo de Soja em Relação ao Grão de Soja. Ciência e Tecnologia de Alimentos 26:571-576.

Silva CE et al. 2012. Teores de isoflavonas em grãos inteiros e nos componentes dos grãos de diferentes cultivares de soja ( $G / y c i n e$ max (L.) Merrill). Brazilian Journal of Food Technology 15:150-156.

Veiga $A D$ et al. 2010. Influência do potássio e da calagem na composição química, qualidade fisiológica e na atividade enzimática de sementes de soja. Ciência e Agrotecnologia 34:953-960.

Venturoli IF and Venturoli S. 2011. Recuperação florestal em uma área degradada pela exploração de areia no Distrito Federal. Ateliê Geográfico 5:183-195.

Wilcox JR and Shibles RM. 2001. Interrelationships among seed quality attributes in soybean. Crop Science 41:11-14.

Yamada LTP et al. 2003. Composição química e conteúdo de ferro solúvel em soja [Glycine max (L.) Merrill]. Ciência e Agrotecnologia 27: 406413. 